(e.g., Köhler, 1923; Needham, 1934). But, such memory "fades" within seconds. Had we used more complex musical stimuli, then, with additional perceptual dimensions such as different rhythms, covert rehearsal might, indeed, have enhanced memory. It is nevertheless of interest to see that with simple musical tone pairs, even though repetition enhances memory, covert rehearsal does not.

\section{REFERENCES}

FARAh, M. J., \& SMITH, A. F. (1983). Perceptual interference and facilitation with auditory imagery. Perception \& Psychophysics, 33, 475-478.

Graefe, T. M., \& Watkins, M. J. (1980). Picture rehearsal: An effect of selectively attending to pictures no longer in view. Journal of Experimental Psychology: Human Learning \& Memory, 6, 156-162.

HALPERN, A. R. (1988). Mental scanning in auditory imagery for songs. Journal of Experimental Psychology: Learning, Memory, \& Cognition, 14, 434-443.
Hubbard, T. L., \& Stoeckig, K. (1988). Musical imagery: Generation of tones and chords. Journal of Experimental Psychology: Learning, Memory, \& Cognition, 14, 656-667.

JoHNSON, R. E. (1980). Memory-based rehearsal. In G. Bower (Ed.), The psychology of learning and motivation (Vol. 14, pp. 263-307). New York: Academic Press.

KöHLER, W. (1923). Zur Theorie des Sukzessivvergleichs und der Zeitfehler. Psychologische Forschung, 4, 115-175.

Needham, J. G. (1934). The time error in comparison judgments. Psychological Bulletin, 31, 229-243.

Watkıns, M. J., \& PeynircioğLu, Z. F. (1981). [Rehearsal of natural sounds]. Unpublished raw data.

Watkıns, M. J., \& PeynircioĞlu, Z. F. (1982). A perspective on rehearsal. In G. Bower (Ed.), The psychology of learning and motivation (Vol. 16, pp. 153-190). New York: Academic Press.

(Manuscript received March 13, 1992.)

\title{
Third International Conference on Visual Search University of Nottingham August 24-27, 1992
}

The Applied Vision Association, the Ergonomics Society, and the British Machine Vision Association and Society for Pattern Recognition are sponsoring the Third International Conference on Visual Search, to be held at the University of Nottingham, U.K., August 24-27, 1992.

This is the third in a series of international conferences devoted exclusively to all aspects of visual search processing. The meeting will encompass both human and machine vision approaches. The sessions will include (but not be limited to): attention and segmentation, eye movements, computer vision, search modeling, and applied aspects of search. There will also be a workshop, and the conference proceedings will be published.

For further information, contact: TICVS, Academic Radiology, University Hospital, Queens Medical Centre, Clifton Boulevard, Nottingham NG7 2UH, U.K. (Tel., 44(0)602 709442; FAX/ANSWERPHONE, 44(0)602 709140). 